\title{
The Analysis of Financial Performance of Bengkulu Government: Approach to the Degree of Fiscal Decentralization
}

\author{
Esti Pasaribu ${ }^{1}$, Septriani $^{2}$, Benardin $^{3}$, Armelly $^{4}$ \\ Department of Development Economics, Bengkulu University, Bengkulu, Indonesia ${ }^{1,2,3,4}$ \\ \{estipasaribu@unib.ac.id ${ }^{1}$, septriani@unib.ac.id², benardin@unib.ac.id ${ }^{3}$ \}
}

\begin{abstract}
This study aims to analyze the financial performance of the Bengkulu Government with a degree of fiscal decentralization approach and to determine the effect of the regional original income (PAD) component on the Financial Performance of Bengkulu Government. The data used in this study was secondary data in the form of time series data and processed by multiple linear regression analysis tools (multiple regression). The empirical results of this study indicate that based on the calculation of the degree of fiscal decentralization ratio, the financial capacity of Bengkulu City is still at a very low capability level which is founded a very large difference between government spending and regional opinion. So it appears that Bengkulu Government still relies on assistance from the central government and was not independent yet. This can be an underline for local government to improve their ability being more independent and capable.
\end{abstract}

Keywords: financial performance; fiscal desentralization

\section{Introduction}

So far, fiscal decentralization has been seen as a solution to the problem of equitable development and the gap between Java and other islands. Since $1^{\text {th }}$ January 2001, local governments have the authority to explore and manage finances independently. The hope is of course, equitable development according to the wishes and potentials of each region so that it becomes more efficient and right on target.

Since the implementation of the decentralization policy, the financial condition of Bengkulu City has shown a tendency to improve. This is indicated by the increase in regional original income (PAD) of the Bengkulu City government from 2000 to 2017. However, if we compare to the amount of expenditure made by the Bengkulu City Government, there was a significant difference between PAD and regional expenditure. The comparison of Regional Original Income (PAD) to regional spending can be seen in Figure 1 below. 


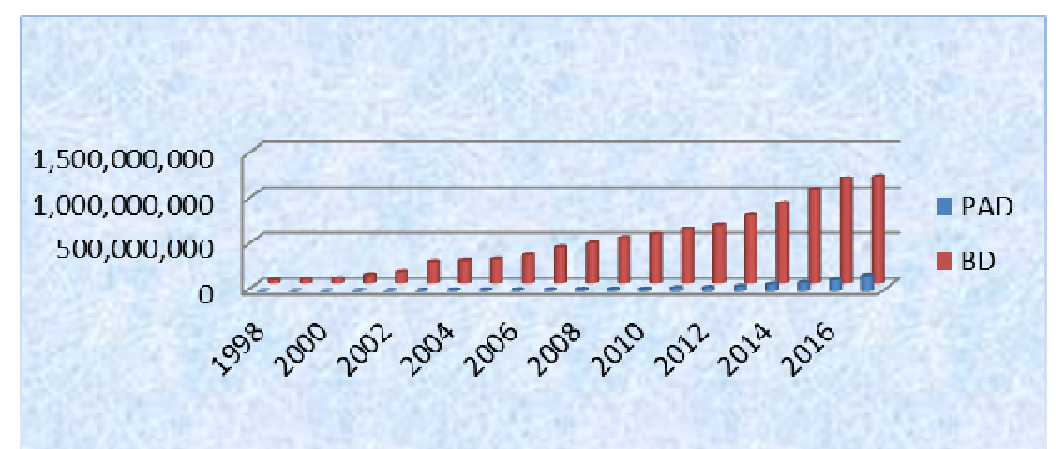

Fig. 1. PAD and Regional Expenditure of Bengkulu City 2000-2017 Source: BPS Bengkulu Province, processed data

Based on Figure 1, it can be seen that most of the regional expenditure does not come from the region's own revenue. It can be concluded that most of Bengkulu city government development expenditures come from central assistance and other legal revenues. This indicates that there were inefficiencies in the financial management of the Bengkulu Government. In addition, the inefficiency in financial performance in Bengkulu was also shown by the realization of PAD in 2017 which only reached Rp174.405.000.000 and when compared to total regional revenue, the ratio of PAD was only 14,86 percent. In general, this indicates the low level of independence of the local governments in Bengkulu Province in financing their purchases.

Pranomo (2014) in his research states that assessing the performance of local governments in managing finances, financial ratio analysis was necessary. This analysis was conducted to see financial performance in order to determine the level of efficiency and effectiveness of the government in managing resources. Thus, it can be seen whether the regional government is already independent in the current period of fiscal decentralization (Pranomo, 2014).

This fiscal decentralization has attracted the attention of many countries, especially in developing countries. Zulianto found that when the fiscal degree was not too high, the fiscal decentralization policy would have a positive effect on the economic growth of a region. Conversely, if the degree of fiscal decentralization is too high, the effect will actually hinder the economic growth of a region (Zulyanto, 2010). Thus, research on fiscal decentralization in a region is important, because the target of central government policy is to achieve economic growth.

For almost twenty years of regional autonomy, is there really economic growth in every region? Have each region been independent in managing their respective resources? Of course, scientific research is should be to answer this questions.

Broadly speaking, similar research has shown that PAD has a positive effect on financial performance. This is evidenced by research conducted by Julitawati et al. PAD has an effect on the financial performance of local governments in Aceh Province(Julitawati, Darwanis, \& Jalaluddin, 2012). This increase in PAD will immediately affect regional spending as well, as evidenced in the research of Fatimah et al, that PAD has a significant effect on regional spending(Fatimah, Nopiyanti, \& Mintoyuwono, 2020).

According to Sidik (Sidik, 2002), regions that have positive Regional Original Income (Pendapatan Asli Daerah-PAD) growth have the possibility to improve economic conditions for the better. However, the problem is that the potential sources of PAD are not yet known, so that they cannot determine the priority scale in making policies to increase Regional Original 
Income (PAD). Therefore, based on these problems, the researcher intends to carry out an analysis of the Financial Performance of the Bengkulu Government, whether it is good or not, and how about the effect of local taxes, regional levies, other legal regional income and the results to the management performance of Bengkulu Government.

\section{Literature Review and Hypothesis}

\subsection{Regional Financial Performance Concept}

Financial performance analysis is basically carried out to assess past performance by conducting analyzes, in order to obtain a financial position that represents the reality of the entity and the potential for future performance. One of the tools used to assess the performance of local governments in regional financial management as outlined in the APBD is financial ratio analysis. In government organizations, to measure financial performance there are several performance measures, namely the ratio of the degree of decentralization, the ratio of regional financial dependence, the ratio of regional independence, the ratio of effectiveness and efficiency, the degree of BUMD contribution, the debt service coverage ratio, and the ratio of debt to regional income.

The degree of decentralization is calculated based on a comparison between the amount of PAD and total regional revenue. This ratio shows the degree of PAD contribution to total regional revenue. The higher the PAD contribution, the higher the capacity of local governments in implementing decentralization. Regional income groups according to Permendagri No. 21 of 2011, namely local revenue, balance funds, and other legal regional revenues. Meanwhile, according to Government Regulation, the balancing fund is replaced by the term transfer income, so that the classification of regional income becomes regional revenue, transfer income, and other legal regional income. Regional Original Income (PAD), consisting ofregional taxes, regional levies, proceeds from the management of separated regional assets, and other legitimate local revenue (Saputra \& Mahmudi, 2012).

\subsection{Previous Research}

Wenny has conducted research on the effect of PAD on local government financial performance (Wenny, 2012) who researched the influence of PAD on financial performance in district and city governments in South Sumatra Province. This research concludes that PAD simultaneously has a significant effect on the financial performance of district and city governments in South Sumatra Province, meaning that all components of PAD greatly affect the financial performance of district and city governments in South Sumatra Province according to the principles of regional autonomy, while partially only other legal PAD which dominantly affects the financial performance of district and city governments in South Sumatra Province, while local taxes, local levies, and company results and regional assets do not dominate the financial performance of district and city governments in South Sumatera Province.

Budianto and Alexander (2016) conducted a study on the effect of PAD and balancing funds on the financial performance of local governments with case studies on districts and cities in North Sulawesi Province. The results of this study show that PAD and balancing funds have a significant effect on government financial performance either partially or simultaneously, where PAD has a significant positive effect while balance funds have a 
negative effect (Budianto \& Alexander, 2016).

In Manado, it was found that PAD and special allocation funds had a significant effect on the expenditure of the City of Manado simultaneously. This research was conducted by Ndede et al with multiple linear analysis. The research also underlines financial independence during the regional autonomy era (Ndede, Sondakh, \& Pontoh, 2016).

In addition, a similar research was also conducted by Antari and Sedana (2018) which examined the effect of PAD and capital expenditures on financial performance in district/city governments in Bali Province. The results of this study indicate that PAD has a significant positive effect on the financial performance of local governments (Antari \& Sedana, 2018). Farhani and Rosnidah tried to analyze financial capacity and financial performance in the implementation of regional autonomy in Cirebon City. This study took a time duration of 2011-2015. The results found that the contribution of PAD was still small and showed low financial performance. However, from year to year, financial capacity seems to be improving (Farhani \& Rosnidah, 2018).

Research related to PAD and government financial performance does not always show positive results. Research conducted by Mulyani and Wibowo actually found that in Central Java the 2012-2015 period there was a negative relationship between PAD and the financial performance of the district / city governments of Central Java Province (Mulyani \& Wibowo, 2017). Regarding financial performance, this study has several hypotheses, namely; first, the financial performance of the Bengkulu City Government is still not good, and the second hypothesis is that local taxes, regional levies, the results of separated regional wealth management, and other legal PAD have a positive and significant effect on the Financial Performance of the Bengkulu City Government. The research framework can be seen in Figure 2.

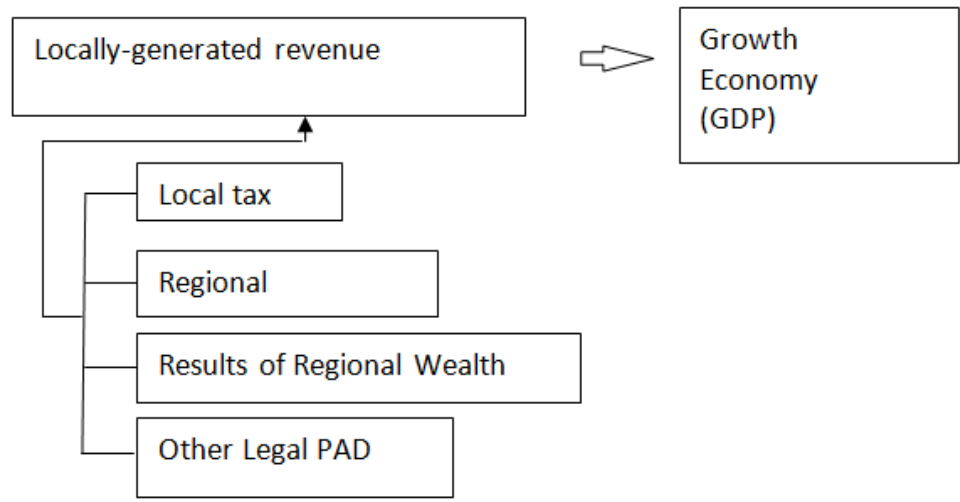

Fig. 2. Research Conceptual Framework

\section{Research Methods}

This study determines the level of financial performance of the Bengkulu City Government by using the fiscal decentralization ratio formula as follows:

$\mathrm{DDF}=\llbracket \mathrm{PAD} \rrbracket \_\mathrm{t} / \llbracket \mathrm{TPD} \rrbracket \_\mathrm{t} \times 100 \%$

Where: 
DDF is the degree of fiscal decentralization

PADt is the total PAD in year $t$

TPDt is the total regional revenue in year $t$

Table 1. Fiscal Decentralization Degree Interval Scale

\begin{tabular}{cc}
\hline $\mathbf{\%}$ & Regional Financial Capability \\
\hline $0.00-10.00$ & Very less \\
$10.01-20.01$ & Less \\
$20.01-30.01$ & Enough \\
$30.01-40.01$ & Moderate \\
$40.01-50.01$ & Well \\
$>50.00$ & Very good \\
\hline
\end{tabular}

After knowing the scale of the Fiscal Decentralization Degree Interval in Bengkulu City, the next step is to test the influence of each Bengkulu City income variable by using an analysis tool, namely multiple regression. According to Gujarati (Gujarati, 2001), regression analysis is basically a study of the dependence of the dependent variable with one or more independent variables with the aim of estimating and or predicting the population mean or average value of the dependent variable based on the known value of the independent variable. The results of the analysis are in the form of coefficients for each independent variable. This coefficient is obtained by predicting the value of the dependent variable with an equation. To get a valid model, the classical assumption test is conducted first. The multiple regression used to meet the research objectives is described below in the form of an equation. The equations used in this study are as follows:

$\mathrm{Yt}=\mathrm{a}+\beta 1 \mathrm{PD}+\beta 2 \mathrm{RD}+\beta 3 \mathrm{HPKDP}+\beta 4 \mathrm{LPS}+\mathrm{e} \pi \mathrm{r}^{\wedge} 2$

Where :

$Y t$ is financial performance

a is a constant,

$\beta 1, \beta 2, \beta 3$ and $\beta 4$ are the regression coefficients of PD, RD and HPKDP and LPS respectively

$\mathrm{PD}$ is the amount of local taxes

$\mathrm{RD}$ is a local levy

HPKDP is the result of separated regional wealth management

LPS is other legitimate local revenue

$\mathrm{e}$ is the error term.

\section{Results and Discussion}

Based on the calculation of the ratio of the degree of fiscal decentralization, it shows that the financial capacity of Bengkulu City is still in the very poor category because most of it is still in the $00.00 \%-10.00 \%$ interval. This is due to the lack of revenue derived from local revenue when compared with total regional revenue. In 2000-2014, the financial capacity based on the ratio of the degree of fiscal decentralization in Bengkulu City was still very lacking, while in 2015 and 2017 it experienced a slight increase with a percentage of above 10 percent, namely with each degree of fiscal decentralization in 2015 amounting to 10.22 percent and in 2017 amounted to 14.87 percent.

The results of the calculation of the ratio of the degree of fiscal decentralization can be 
seen in table 1 below:

Table 2. Calculation of Fiscal Decentralization Degree Ratio in Bengkulu City, 2000-2017

\begin{tabular}{rrrcc}
\hline Year & PAD (Rp) & \multicolumn{1}{c}{ PD (Rp) } & DDF (\%) & Financial Capability \\
\hline 2000 & $3,386,048,000$ & $59,760,551,000$ & 5.67 & Very less \\
2001 & $5,169,968,000$ & $99,326,402,000$ & 5.21 & Very less \\
2002 & $6,801,494,000$ & $158,678,383,000$ & 4.29 & Very less \\
2003 & $9,685,802,000$ & $219,972,922,000$ & 4.40 & Very less \\
2004 & $15,334,910,000$ & $216,670,719,000$ & 7.08 & Very less \\
2005 & $14,148,848,961$ & $217,693,648,000$ & 6.50 & Very less \\
2006 & $16,702,355,000$ & $345,632,353,000$ & 4.83 & Very less \\
2007 & $17,885,739,044$ & $405,039,728,890$ & 4.42 & Very less \\
2008 & $24,562,456,000$ & $453,141,762,000$ & 5.42 & Very less \\
2009 & $26,941,306,000$ & $475,664,056,000$ & 5.66 & Very less \\
2010 & $26,677,744,000$ & $535,671,774,000$ & 4.98 & Very less \\
2011 & $39,318,037,000$ & $611,815,153,000$ & 6.43 & Very less \\
2012 & $41,626,605,000$ & $677,136,280,000$ & 6.15 & Very less \\
2013 & $55,979,830,000$ & $793,506,065,000$ & 7.05 & Very less \\
2014 & $81,755,212,000$ & $937,898,451,000$ & 8.72 & Very less \\
2015 & $96,805,459,000$ & $946,911,913,000$ & 10.22 & Less \\
2016 & $110,939,655,000$ & $1,134,818,232,000$ & 9.78 & Very less \\
2017 & $174,405,000,000$ & $1,173,222,671,692$ & 14.87 & Less \\
\hline
\end{tabular}

Source: Research results, processed data, 2018

Based on the ratio of the degree of fiscal decentralization, the financial capacity of Bengkulu Government was in a very low level, namely with an average degree of fiscal decentralization of $6,76 \%$ or in the range of $00,00 \%-10,00 \%$. The low degree of fiscal decentralization shows that the government was not sufficiently able to finance all its needs. Most of Bengkulu expenditure was very depend on the central government and also shows that Bengkulu Government have to increase Regional Original Income (PAD) such as local taxes, user fees and others. If we compare PAD with the total amount of expenditure made by the Bengkulu City, then there was a significant difference. Complete research results can be seen in table 2.

Table 3. Model Estimation Results

\begin{tabular}{ccccc}
\hline Variable & Coefficient & Std.Error & t-statistic & Prob. \\
\hline (constant) & -4.677294 & 13.81793 & -0.338495 & 0.7404 \\
LNRD & -2.716032 & 0.775670 & -3.501529 & 0.0039 \\
LNPD & 3.717779 & 1.111159 & 3.345857 & 0.0053 \\
LNHPKD & 0.029350 & 0.094855 & 0.309416 & 0.7619 \\
LN & -0.675459 & 0.708034 & -0.953993 & 0.3575 \\
\hline $\mathbf{R}^{\mathbf{2}=\mathbf{0 . 7 6 8 9 0 8}}$ & & $\mathrm{F}=0.81364$ & \\
Adjusted R $^{\mathbf{2}}=\mathbf{0 . 6 9 7 8 0 2}$ & & $\alpha=0.05$ & \\
& & & $\mathrm{~N}=18$ & \\
\hline
\end{tabular}

Source : Research results, processed data, 2018

\subsection{The Effect of Local Taxes on the Financial Performance of Bengkulu City}

Based on the $t$ test, the $F$ test and the coefficient of determination $\left(\mathrm{R}^{2}\right)$, the results were obtained respectively. Based on the t test, the t-statistic value is obtained 3,345 (positive value) with a probability of 0,0053 and with an $1 \mathrm{~A}$ of 3,717 . This shows that partially local 
taxes have a positive and significant effect on the financial performance of Bengkulu Government. This means that when local taxes have increased by 1 percent, then financial performance will increase by 3,717 percent.

This result is in accordance with the hypothesis that there is a significant effect of local taxes on the financial performance of Bengkulu City. This means that the amount of local taxes is very influential on regional financial performance. This is of course a material for evaluation and at the same time a challenge for the Bengkulu City government to continue to improve regional financial performance. Moreover, if we look at the results of the analysis of the financial performance of Bengkulu City using the degree of fiscal decentralization approach, the results tend to be unsatisfactory.

Although the regional taxes of Bengkulu City have experienced a significant increase, reaching an average growth of 28,6 percent per year, it still needs to be optimized in order to improve the financial performance of the Bengkulu City government so that it does not rely too much on the central government. As for the regional taxes of Bengkulu City that must be optimized, among others; parking tax, advertisement tax, hotel tax, restaurant tax, entertainment tax, advertisement tax, Class $\mathrm{C}$ extraction and processing tax, ground water tax and other taxes.

\subsection{The Effect of Local Retribution on the Financial Performance of Bengkulu City}

Based on the $t$ test, the $F$ test and the coefficient of determination $\left(R^{2}\right)$, the results were obtained respectively. Based on the $t$ test, the $t$-statistic value is obtained $-3,50$ (negative value) with a probability of 0.0039 and with a coefficient of $-2,716$. This shows that partially local charges have a negative and significant effect on the financial performance of the Bengkulu City government at $a=0.05$. This means that when the local levies have increased by 1 percent, the financial performance will decrease by 2,7 percent. This result is not in accordance with the hypothesis that there is a significant effect on the financial performance of the Bengkulu Government.

The results of this study indicate that the higher the local retribution revenue, the lower the financial performance of Bengkulu City. This is because at the same time, the increase in regional user fees is not followed by an increase in regional original income in proportion to regional revenue. This means that there are other variables such as local taxes, other legal PAD and the resulting separated regional assets do not increase proportionally to regional income. In other words, when local retribution has decreased, on the other hand, PAD in Bengkulu City has continued to increase. In addition, this is also due to the fact that the large contribution of PAD to regional revenues is not proportional to the large percentage of aid funds from the center.

\subsection{Effect of the Results of Separated Regional Wealth Management on the Financial Performance of Bengkulu City}

Based on the $t$ test, the $F$ test and the coefficient of determination $\left(\mathrm{R}^{2}\right)$, the results were obtained respectively. Based on the $t$ test, the $t$-statistic value is obtained 0,309 (positive value) with a probability of 0.7619 and with a coefficient of 0,0293 This shows that partially the regional levies have a positive but insignificant effect on the financial performance of the Bengkulu City government at $a=0,05$, so it can be concluded that the results of separated regional wealth management have no effect on financial performance.

Proceeds from the Management of Separated Regional Assets are revenues in the form of 
proceeds from regional owned companies and proceeds from the management of separated regional assets, which consist of a portion of the profits of the Regional Drinking Water Company, a share of profits from bank financial institutions, a share of profits from non-bank financial institutions, a share of profits from regional companies others, and a share of the return on equity / investment in third parties.

If a regional company has been established based on this law, then the company's capital consists of all or part of the assets separated from the regional expenditure budget will still be included in the regional wealth balance. Thus the sizeproceeds from the management of separated regional assetsobtained did not have an impact on the increase / decrease in the financial performance of the Bengkulu City Government. This is caused by the results of separated regional wealth management constantly fluctuate and tend to increase with an average annual growth rate of 68,6 percent.

In addition, when compared to other PAD sources, the segregated regional wealth yields have a relatively smaller contribution when compared to other PAD sources. This is caused by the number of regional-owned companies in Bengkulu City is still relatively small. Uncertainty, the results of the management of regional wealth which are separated each year do not really contribute significantly to PAD. This has an impact also on the low influence of the results of separated regional wealth management on financial performance.

\subsection{Other Effects of Legal PAD on the Financial Performance of Bengkulu City}

Based on the $t$ test, the $F$ test and the coefficient of determination $\left(\mathrm{R}^{2}\right)$, the results were obtained respectively. Based on the $t$ test, the t-statistic value is obtained -0,953 (negative value) with a probability of 0.3575 and with a coefficient of $-0,675$. Partially, local levies have a negative and insignificant effect on the financial performance of the Bengkulu City government at $a=0,05$, so it can be concluded that the results of separated regional wealth management have no effect on financial performance.

Other legitimate regional income is the original regional income consisting of the proceeds from the sale of regional assets that cannot be separated, giro services, interest receipts, compensation for regional assets, commissions, deductions and gains from the rupiah exchange rate, fines for late implementation of work, tax penalties, retribution penalties., the results of the execution of guaranteed income from returns, social facilities and public facilities, income from the provision of education and training, income from sales installments/installments and others. As for the reason for the insignificance of the results of this study is because the amount of other legal PAD fluctuates every year and does not really contribute significantly to regional original income.

\section{Conclusion}

Based on the results of the analysis and previous discussion, the following conclusions can be drawn:

a. Based on the calculation of the ratio of the degree of fiscal decentralization, the financial capacity of Bengkulu Government was still at a very low level, an average degree of fiscal decentralization was $6,76 \%$ or in the range of $00,00 \%-10,00 \%$.

b. Simultaneously, local taxes, levies, results of separated regional wealth management, and other legal PAD have a positive and significant effect on the Financial Performance of 
the Bengkulu Government at $\delta=0,5$. Meanwhile, partially, each local tax has a positive and significant effect on the financial performance of Bengkulu City at $\delta=0,5$. The regional levies have a negative and significant effect on the financial performance of Bengkulu City at $\delta=0,5$, while the results of separated regional wealth management and other legal PAD do not affect the financial performance of Bengkulu City at $\delta=05$.

\section{Limitations and Suggestions}

The limitations in this study are as follows:

a. This study is only limited to the financial performance of the Bengkulu City Government with a relatively short period of time. The hope is that further researchers can study the entire financial performance of local governments with a wider scope and add to the analysis period.

b. This research also only includes variables of local taxes, local levies, the results of separated regional wealth management, and other legitimate local revenue. In subsequent studies, researchers can include other income variables outside of Regional Original Income (PAD), such as the General Allocation Fund (DAU) and the Special Allocation Fund (DAK) or capital expenditure if you want to get a more complete picture of the effect of income on financial performance.

Based on this research, there are several suggestions that the researcher wants to convey, including:

a. In an effort to improve the financial performance of the Bengkulu City government, the regional government of Bengkulu City should make efforts to optimize Regional Original Revenue and not rely too much on assistance from the center.

b. In order to minimize insignificant research results, you should select variables which are theoretically and based on research influential in entering variables.

\section{References}

[1] Antari, N. P. G. S., \& Sedana, I. B. P.: Pengaruh Pendapatan Asli Daerah dan Belanja Modal Terhadap Kinerja Keuangan Pemerintah Daerah. E-Jurnal Manajemen Universitas Udayana. https://doi.org/10.24843/ejmunud.2018.v7.i02.p19, (2018)

[2] Budianto, B., \& Alexander, S.: Pengaruh PAD dan Dana Perimbangan Terhadap Kinerja Keuangan Pemerintah Kabupaten/Kota di Provinsi Sulawesi Utara. Jurnal Riset Ekonomi, Manajemen, Bisnis Dan Akuntansi. https://doi.org/10.35794/emba.v4i4.14511 (2016)

[3] Farhani, F., \& Rosnidah, I.: Analisis Kemampuan Keuangan Dan Kinerja Keuangan Daerah Dalam Pelaksanaan Otonomi Daerah (Studi Kasus APBD Kota Cirebon Tahun Anggaran 2011- 2015). "REFORMASI: Jurnal Ilmiah Administrasi." https://doi.org/10.33603/reformasi.v3i1.1788 (2018)

[4] Fatimah, N. N., Nopiyanti, A., \& Mintoyuwono, D.: Pengaruh Pendapatan Asli Daerah dan Dana Perimbangan terhadap Belanja Daerah. EQUITY. https://doi.org/10.34209/equ.v22i2.936 (2020)
Gujarati,
D.
N.:
Basic
Econometrica. https://doi.org/10.1016/j.aquaculture.2013.02.043 (2001) 
[6] Julitawati, E., Darwanis, \& Jalaluddin.: Pengaruh Pendapatan Asli Daerah (Pad) Dan Dana Perimbangan Terhadap Kinerja Keuangan Pemerintah Kabupaten/Kota Di Provinsi Aceh. Jurnal Akuntansi Pascasarjana Universitas Syiah Kuala. Vol 2 pp 1328 (2012)

[7] Mulyani, S., \& Wibowo, H: Pengaruh Belanja Modal, Ukuran Pemerintah Darah, Intergivernmental Revenue dan Pendpatan Asli Daerah Terhadap Kinerja Keuangan (Kabupaten/Kota Di Provinsi awa Tengan, Yahun 2012-2015). Jurnal Ilmiah Akuntansi. Vol 4, pp 1-12 (2017)

[8] Ndede, Y., Sondakh, J. J., \& Pontoh, W.: Pengaruh Pendapatan Asli Daerah ( PAD ) dan Dana Anggaran Belanja Modal Di Kota Manado. Jurnal Berkala Ilmiah Efisiensi (2016)

[9] Pranomo, J.: Analisis Rasio Keuangan Untuk Menilai Kinerja Keuangan Pemerintah Daerah (Studi Kasus Pada Pemerintah Kota Surakarta).(Joko Pramono). Jurnal Ilmiah Among Makarti Vol 3, pp 26-38 (2016)

[10] Saputra, B., \& Mahmudi.: Pengaruh Desentralisasi Fiskal terhadap Pertumbuhan Ekonomi dan Kesejahteraan Masyarakat. Jurnal Akuntansi Dan Auditing Indonesia (2012)

[11] Sidik, M.: Optimalisasi pajak daerah dan retribusi daerah dalam rangka meningkatkan kemampuan keuangan daerah. Makalah Disampaikan Acara Orasi Ilmiah. Bandung (2002)

[12] Wenny, C. D.: Analisis Pengaruh Pendapatan Asli Daerah (PAD) Terhadap Kinerja Keuangan Keuangan Pada Pemerintah Kabupaten Dan Kota Di Propinasi Sumatera Selatan. Forum Bisnis Dan Kewirausahaan Jurnal Ilmiah STIE MDP pp. 39-51 (2012).

[13] Zulyanto, A.: Pengaruh Desentralisasi Fiskal terhadap Pertumbuhan Ekonomi di Provinsi Bengkulu. Jurnal Ekonomi (2010) 